\title{
Internal transcribed spacer (ITS) sequence-based identification of yeast biota on pomegranate surface and determination of extracellular enzyme profile
}

\author{
TÜLAY TURGUT GENÇ ${ }^{1, \boldsymbol{v}}$, MELIH GÜNAY ${ }^{2}$ \\ ${ }^{1}$ Department of Biology, Faculty of Arts and Science, Çanakkale Onsekiz Mart University. Terzioğlu Campus, 17100, Çanakkale, Turkey. \\ Tel./fax.: +90-286-2180018-ext.1795, `email: tturgutgenc@comu.edu.tr \\ ${ }^{2}$ Department of Biology, Graduate School of Natural and Applied Sciences, Çanakkale Onsekiz Mart Universit. Terzioğlu Campus, 17100, Çanakkale, \\ Turkey. Tel. +90-286-2180018, email: melihgunay@ comu.edu.tr
}

Manuscript received: 31 January 2020. Revision accepted: 24 April 2020

\begin{abstract}
Genc TT, Günay M. 2020. Internal transcribed spacer (ITS) sequence-based identification of yeast biota on pomegranate surface and determination of extracellular enzyme profile. Nusantara Bioscience 12: 59-67. Yeasts are the most significant organisms to produce fermented products from different types of fruits such as grape, strawberry and pomegranate. The native yeasts on these fruits contribute to beverages' quality and aroma during fermentation. Pomegranate is used in fruit juice and wine production because of high antioxidant characteristic. In order to determine yeast microbiota on the pomegranate fruits collected from Gallipoli (Gelibolu), Çanakkale-Turkey, ITS-5.8S rDNA gene region have been utilized. Also, phylogenetic relationships among identified yeast species were assigned by using sequences of ITS-5.8S rDNA gene region. In addition, extracellular enzyme activity of identified yeast strains was detected by using API-ZYM. Kluyveromyces lactis, Aureobasidium pullulans, Hanseniaspora uvarum, Candida zeylanoides, Kwoniella sp., and Metschnikowia pulcherrima and Metschnikowia ziziphicola yeast species were identified on pomegranate surface. Phylogenetic analysis, carried out in ITS-5.8S rDNA gene region of identified yeast strains, revealed the presence of five clades. Kwoniella sp., H. uvarum, M. pulcherrima, and Kl. lactis yeast strains revealed high leucine arylamidase activity. Also valine arylamidase activity was determined in $M$. pulcherrima and $\mathrm{Kl}$. lactis yeast species. Acid phosphatase activity was determined in $H$. uvarum and $K$. lactis yeast species. Uncultured Kwoniella sp. and H. uvarum yeast species displayed high $\beta$-galactosidase and $\beta$ glucosidase activities, respectively.
\end{abstract}

Keywords: API-ZYM, ITS, PCR-RFLP, pomegranate, yeast microbiota

\section{INTRODUCTION}

Yeasts have been used to produce foods (cheese, bread and dairy products etc.) and beverages (beer and wine etc.) for centuries (Braduardi and Porro 2012). They have an important role in the determination of food quality and production of fermented foods. Because of high fermentation ability, yeasts are utilized to fabricate alcohol, beer, wine, cake and to produce secondary metabolites, such as antibiotics and vitamins (Hierro et al. 2004; Lee 1996, Lopez et al. 2001). Some of yeasts also contribute to the developing of flavored beverages. Thus, they can be used as starter culture in the fermentation process.

Enzymes are utilized in different perspectives, such as detergents, textile, biofuels industry, food-producing, animal feeds, and medical fields. Food enzymes are generally applied in baking industry, fruit juice, and dairy products, winemaking. The activity of enzymes during these processes increases their flavor and nutritional value (Wang et al. 2012). Several enzymes, having industrial and biotechnological importance, can be produced by Saccharomyces cerevisiae and various non-Saccharomyces yeast strains such as Kluyveromyces lactic, Geotrichum candidum, Yarrowia lipolytica, Rhodotorula spp., Kluyveromyces marxianus, Komagataella pastoris,
Debaryomyces hansenii, Cryptococcus spp., Cryptococcus laurentii, Sporobolomyces salmonicolor etc. (Johnson 2013a, b). Hence, the determining of yeast microbiota and the understanding of enzyme activity is important for industrial and biotechnological studies.

Pomegranates (Punica granatum L.) contains variety of polyphenols such as ellagic acid and punicalagins, both of which are thought as strong antioxidants. Punicalagins are found only on surface of pomegranate and they have 2 -fold of antioxidant ability of green tea and red wine. Pomegranate is used for producing vinegar, wine, liqueur, jam, pomegranate molasses, pomegranate juice, and for a coloring agent of food and enhancing flavor. Due to high sugar content of pomegranate, it can be used to manufacture of pomegranate wine (Bakoyianis et al. 1992, Sevda and Rodrigues 2011). The extracts of pomegranate fruits have antifungal and antimicrobial features (Dağcı and Dığrak 2005). In addition, pomegranate enhances the longevity, fertility, and growth rate of the nematode Caenorhabditis elegans (Kılıçgün et al. 2015). The peel of pomegranate includes phenolic compounds and has high antioxidant activity (Yasoubi et al. 2007).

There are different types of identification and classification methods for yeast species. These methods have generally depended on morphological, physiological 
features and biochemical characteristics of yeasts species (Kurtzman and Fell 1998; Barnett et al. 2000; Kreger-van Rij 1984), plus the DNA-based molecular techniques such as ribosomal DNA sequencing, DNA-DNA hybridization and RFLPs of chromosomal DNA (Kurtzman and Robnett 1998; Vaughan and Martini 1987; Török et al. 1993; Versavaud and Hallet 1995). The ribosomal DNA genes containing 5S, 5.8S, $18 \mathrm{~S}$ and 26S (D1/D2 domain) coded regions and non-coded ITS (Internal Transcribed Spacers) and IGS (Intergenic Spacer) regions and their restriction profiles have been used to identify yeast species (Kurtzman and Robnett 1998; Baleiras Couto et al. 2005; Gonzalez et al. 2007; Sabate et al. 2002; Cadez et al. 2002; Diaz and Fell 2000; Naumova et al. 2003; Guillamon et al. 1998; Esteve-Zarzoso et al. 1999).

The aim of this study was to identify yeast microbiota on the pomegranate collected from Gallipoli (Gelibolu), Çanakkale-Turkey, and to determine of extracellular enzyme activity of all yeast strains. For this purpose, we used two molecular techniques, PCR-RFLP analysis and sequencing of ITS-5.8S rDNA gene region and we used API-ZYM test system for characterization of extracellular enzyme activity. Also we constructed phylogenetic tree to analyzed relationships among identified yeast species.

\section{MATERIALS AND METHODS}

\section{Sampling and isolating yeast strains}

Taking into account of pomegranate ripening period, fruit samples were collected from Koruköy, GeliboluTurkey in August, and November in 2008. Pomegranate samples were homogenized in $2 \%$ Sodium citrate solution after weighting and spread onto YGC-Agar medium (40 gr/l Yeast Extract Glucose Chloramphenicol Agar) including $0.1 \%$ Sodium propionate. After incubation of plates at $30{ }^{\circ} \mathrm{C}$ for $2-3$ days, the appeared yeast colonies were counted to determine the colony-forming units (CFU/gr) and then transferred to YPD medium (10 gr/l (w/v) Yeast Extract Powder, $20 \mathrm{gr} / \mathrm{l}$ (w/v) Bacto-peptone, , $20 \mathrm{gr} / \mathrm{l}(\mathrm{w} / \mathrm{v})$ Agar, 2\% Dextrose) and incubated at same conditions for 2-3 days. The isolated yeast strains were stored in $20 \%$ glycerol at $-80^{\circ} \mathrm{C}$ for further use.

\section{Procedures}

\section{Genomic DNA isolation and pcr amplification}

Yeast strains, grown on YPD medium, were used in genomic DNA isolation method which was previously improved (Sherman et al. 1986). ITS1-5.8S-ITS2 rDNA gene regions of genomic DNA were amplified by using yeast specific primers ITS1 $15^{\prime}$ TCCGTAGGTGAACCTGCGG-3') and ITS4 (5'TCCTCCGCTTATTGATATGC-3'). PCR amplification was studied by using previously reported conditions (White et al. 1990). PCR reactions were carried out with BIORAD Thermal cycler in $25 \mu \mathrm{l}$ final volume containing 1.25U Recombinant Taq DNA polymerase (Thermo Scientific-EP0402) $10 \mathrm{pmol} / \mu \mathrm{l}$ of each primer, $10 \mathrm{mM}$ of each dNTP, 10X PCR reaction buffer, $3 \mathrm{mM} \mathrm{MgCl} 2$ and 50-100 ng genomic DNA as template. The PCR conditions were: initial denaturation at $95^{\circ} \mathrm{C}$ for $1.5 \mathrm{~min} ; 30$ cycles of denaturing at $94^{\circ} \mathrm{C}$ for $2 \mathrm{~min}$; annealing at $60^{\circ} \mathrm{C}$ for $1 \mathrm{~min}$, an extension at $72^{\circ} \mathrm{C}$ for $2.5 \mathrm{~min}$; and a final extension step of $5 \mathrm{~min}$ at $72^{\circ} \mathrm{C}$. The products were electrophoresed in $1.5 \%$ agarose gel and visualized. The length of PCR amplicons were calculated using by Gel-Pro Analyzer v4.0 software.

\section{Restriction profiles and DNA sequencing}

PCR amplicons were purified using GeneJet PCR Purification Kit (Thermo Scientific-K0702) and then were digested with HaeIII, HinfI, MspI, HhaI and AluI restriction endonucleases according to supplier's instructions. The restriction fragments were analyzed by electrophoresis in 3\% agarose gel and photographed. The length of restriction fragments was calculated by using GelPro Analyzer v4.0 software. The yeast strains were grouped with respect to restriction profiles and 10 groups was formed. PCR products of all yeast strains were sequenced by using the Applied Biotechnologies 3500xl Genetic Analyzer. The obtained ITS1-5.8S ITS2 sequences were analyzed using Basic Local Alignment Search Tool (BLAST) on National Center for Biotechnology Information (NCBI) (Altschul et al. 1990). During BLAST analysis, the yeast strains having high sequence similarity were selected as reference yeast strains, mainly belong to the CBS-Knaw Yeast Collection. The resulting sequences were deposited in GenBank (Accession numbers: KR011878, KY366236-KY366245, MK613238MK613271 for the ITS1-5.8S-ITS2 sequences).

\section{Phylogenetic analysis}

Phylogenetic relationship among the yeast strains was analyzed using Maximum Parsimony (MP) in MEGA-X (Kumar et al. 2018). Nucleotide sequences of ITS1-5.8SITS2 rDNA gene region of 47 yeast strains and 2 outgroup (S. cerevisiae and $P$. guilliermondii) were aligned with ClustalX algorithm in MEGA-X. MP tree was obtained using the Subtree-Pruning-Regrafting (SPR) algorithm and bootsrap method in MEGA-X. 1000 bootstrap replicates were used to defined branch support.

\section{Extracellular enzyme profiles}

Extracellular enzyme profiles of yeast strains were determined by using API-ZYM kit system (bioMérieux, France), which is a minimized and semi-quantitative test system. API-ZYM is utilized for screening 19 different enzyme activities (Alkaline phosphatase, Esterase (C 4), Esterase Lipase (C 8), Lipase (C 14), Leucine arylamidase, Valine arylamidase, Cysteine arylamidase, Trypsin, $\alpha-$ chymotrypsin, Acid phosphatase, Naphthol-AS-BIphosphohydrolase, $\alpha$-galactosidase, $\beta$-galactosidase, $\beta$ glucuronidase, $\alpha$-glucosidase, $\beta$-glucosidase, $N$-acetyl- $\beta$ glucosaminidase, $\alpha$-mannosidase, $\alpha$-fucosidase). All yeast strains were grown in YPD culture at $30{ }^{\circ} \mathrm{C}$ for 12 hours (till the exponential stage) with constant shaking (120 $\mathrm{rpm} / \mathrm{rev}$ ). The $65 \mathrm{~mL}$ from the saturated yeast culture was transferred to each microwells of API-ZYM strip. The APIZYM strips were incubated at $30{ }^{\circ} \mathrm{C}$ for 4 hours. Then, ZYM A and ZYM B reagents were added to each cupule 
and all the strips were incubated at room temperature for 5 minutes. Enzyme profiles of yeast strains were defined by color scalar of API-ZYM kit system. Enzyme activities were carried out in duplicate for each strain to confirm the results.

\section{RESULTS AND DISCUSSION}

\section{Results}

Pomegranate samples were collected from Koruköy, Gelibolu-Turkey in 2008 during ripening period. After incubation on YGC medium, 47 yeast strains were isolated and colony-forming units (CFU/gr) were calculated as $3.7 \times 10^{3} \mathrm{gr}^{-1}$. The isolated yeast strains were classified into 8 groups according to their colony morphologies such as colony form (circular, irregular, etc.), colony elevation (raised, convex, flat, etc.) and colony margin (entire, undulate, filiform, etc.) (data not shown).

After genomic DNA extraction, the yeast strains were classified into four groups according to PCR amplicons of ITS1-5.8S-ITS2 rDNA gene regions (Table 1). The first group composed of 6 yeast strains with nearly 400bp in PCR amplicon length. In the second and third groups contained 21 and 8 yeast strains having PCR length between 600 to $700 \mathrm{bp}$. The last group represented 12 yeast strains giving a PCR amplicon with 750-800 bp in length. All yeast members of PCR groups were digested with five restriction endonucleases (HinfI, HaeIII, MspI, AluI, and HhaI) and analysis of PCR-RFLP results was given in Table 1. The yeast strains present in Group I, Group III, and Group IV displayed two different restriction profiles while Group II gave 4 different RFLP profiles. The yeast strain P-48 was distinguished from other strains in Group I with HaeIII digestion. All yeast strains in this group were not cleaved by AluI restriction enzyme. Third PCR group was separated into two restriction profiles by the action of four restriction enzymes (HinfI, HaeIII, MspI, and HhaI) except AluI. And the members of last PCR group, Group IV, did not have a cleavage site for MspI. The yeast strains in this group showed different profiles with respect to digestion of HinfI, HaeIII, AluI, and HhaI restriction enzymes except for MspI. Group II yeast strains showed 4 restriction profiles with respect to HaeIII, MspI, AluI, and HhaI digestions. HinfI restriction enzyme gave same restriction profile in all strains of Group IV. According to PCR-RFLP results, we obtained 10 different restriction profiles that can represent ten different yeast species. These results showed that the restriction enzymes used in RFLP analysis were suitable to discriminate yeast strains.

ITS1-5.8S-ITS2 rDNA gene region of all yeast strains was sequenced and BLAST analysis was carried out of yeast strains. The resulting sequences were submitted to the GenBank database and accession numbers were obtained. The yeast species which show sequence similarity, were given in Table 2 along with reference accession number on GenBank Database. According to the BLAST analysis of ITS1-5.8S-ITS2 rDNA gene region, while 28 yeast strains showed 96 to $99 \%$ similarity with their reference yeast species, 18 yeast strains gave range from $80 \%-83 \%$ sequence similarity with Kwoniella bestiolae (Cryptococcus bestiolae) (Ref. Acc. Numbers KY103928.1). Therefore, the yeast strains present in third (P-1, P-4, P-5, P-6, P-7, P-9, P-11, P-12, P-19, P-22, P-26, $\mathrm{P}-39, \mathrm{P}-41$ and $\mathrm{P}-42)$, fifth (P-15), sixth (P-30, $\mathrm{P}-31)$ and eight (P-14) restriction profiles were determined as an uncultured Kwoniella sp. The yeast strains, P-3, P-21, P-24, and $\mathrm{P}-27$, localized in fourth restriction profile with respect to PCR-RFLP results. Despite the fact that P-21 yeast strain has different colony morphology than their group members, according to the sequence analysis of P-3, P-21, P-24, and P-27 strains, they showed similarity with Aureobasidium pullulans (Ref. Acc. No. KT898651.1). During BLAST analysis, the four yeast strains cannot give any match with A. pullulans yeast strain that belongs to the CBS yeast database. So, the results of four yeast strains were obtained from the NCBI-BLAST database giving highest sequence similarity (98-100\% identity). The sequence analysis of 6 yeast strains having first and second restriction profile, $\mathrm{P}$ 47, P-49 and P-55a yeast strains gave 98\% sequence similarity with M. ziziphicola (Ref. Acc. No. KY104214.1). P-25a, P-53, and P-48 yeast strains showed sequence similarity with $M$. pulcherrima \%97, \%92, and \%98 respectively (Ref. Acc. No. KY104205.1). We also observed that all six yeast strains produced pulcherrimin pigment. The yeast strains belonging to seventh (P-20, P25b, P-29, P-32, P-33, P-34 and P-35) and ninth (P-8, P-23, P-36, P-37, P-38, P-44, P-46, P-50, P-51, P-52 and P-55b) restriction profiles were identified as Candida zeylanoides (Ref. Acc. No. KY102548.1) and Hanseniaspora uvarum (Ref. Acc. No. KY103563.1), respectively. P-18 strain demonstrated $99 \%$ similarity with Kluyveromyces lactis (Ref. Acc. No. KY103775.1) yeast species. These results also supported the idea that the yeast strains with different restriction profiles may be the same species, as in the case of Kwoniella sp. yeast strains. The percent distribution of yeast species on the pomegranate surface was determined as: $38.30 \%$ Kwoniella sp., $23.40 \%$ H. uvarum, $14.9 \%$ C. zeylanoides, $6.38 \%$ M. pulcherrima and M. ziziphicola, $8.51 \%$ A. pullulans and $2.13 \%$ K. lactis. It was observed that Kwoniella sp. and $H$. uvarum yeast species were dominant on surface yeast microbiota of pomegranate.

The phylogenetic analysis of all yeast strains was carried out by using MEGA-X phylogenetic analysis tool. ITS1-5.8S-ITS2 rDNA gene sequences of yeast strains were aligned by the ClustalX v1.6 algorithm and Maximum parsimony tree was constructed. All of analysis was done by using MEGA-X. 1000 bootstrap replicates were used to defined branch support. The percentage of trees is shown next to the branch and frequencies under $50 \%$ are not given. When the MP tree is analyzed, we obtained five clades. The first clade is composed of 24 yeast strains and divided into two cluster as Kwoniella sp. (19) with reference yeast strain (CBS:10118) and A. pullulans (5) with reference yeast strains (KT898651.1). The second clade includes $H$. uvarum yeast strains (12) with reference strain (CBS:104). Third clade consist of Kl. lactis and reference strain (CBS:739). The fourth clade consist of 8 yeast strains belongs to Metschnikowia genus, $M$. pulcherrima (3), M. ziziphicola (3) and their reference 
strains (for M. pulcherrima, CBS:5833; for M. ziziphicola, CBS:10358). The fifth clade includes $C$. zeylanoides yeast strains (8) with reference strain (CBS:641), only one strain (KY366245) was separated from others in the clade (Figure 1).

The extracellular enzymatic activities of all isolated yeast strains were screened by using API-ZYM (Bio Mérieux, France) kit system. The level of enzyme activity was determined with respect to API-ZYM color reaction chart from zero (no activity) to five (highest activity), and results were given in Table 3 . Trypsin, $\alpha$-chymotrypsin, $\alpha$ galactosidase, $\quad \beta$-glucuronidase, $\quad \mathrm{N}$-acetyl- $\beta$ glucosaminidase, $\alpha$-mannosidase, and $\alpha$-fucosidase enzyme activities were not detected in the yeast strains. All yeast strains showed intermediate level of esterase lipase and leucine arylamidase enzyme activities. All strains of $M$. pulcherrima, A. pullulans, and $K$. lactis showed similar patterns in their enzyme activities. But the strains of Kwoniella sp., H. uvarum and C. zeylanoides exhibited two different enzymatic patterns. The strains of Kwoniella sp., P-1, P-5, P-6, P-7, P-9, P-11, P-19, P-26, P-31, P-41, P-42, possessed high $\beta$-galactosidase activity and the strains of H. uvarum, P-8, P-36, P-44, P-46, P-50, P-51, P-52, showed high $\beta$-glucosidase activity. However, the other strains of Kwoniella sp., P-4, P-12, P-14, P-15, P-22, P-30 and $\mathrm{P}-39$, and $H$. uvarum, $\mathrm{P}-23, \mathrm{P}-37, \mathrm{P}-38$ and $\mathrm{P}-55 \mathrm{~b}$, did not have $\beta$-galactosidase and $\beta$-glucosidase activity, respectively. $M$. pulcherrima yeast strains have moderate level of $\alpha$-and $\beta$-glucosidase activity.

\section{Discussion}

Pomegranate juice can positively affect the protein synthesis of $S$. cerevisiae and significantly decrease oxidative damage (Aslan et al. 2014). The fruits have a high nutritional value because of polyphenol content. Both the fruit and its extract have antibacterial, anticancer, and antioxidant activity as well as stress protectant ability
(Santos et al. 2012). Therefore, in this study, we determined the yeast microbiota present on pomegranate surface, PCR-RFLP, and ITS1-5.8S-ITS2 rDNA gene sequence analysis was used for yeast identification and classification. We also detected extracellular enzyme profiles using API-ZYM test system.

ITS1-5.8S-ITS2 gene region of yeast strains was amplified and cleaved by using HinfI, HaeIII, MspI, AluI, and HhaI restriction enzymes. ITS1-5.8S-ITS2 gene region of all isolated yeast strains were sequenced and analyzed in BLAST tool on NCBI. M. pulcherrima, M. ziziphicola, Kwoniella sp., A. pullulans, C. zeylanoides, $H$. uvarum and $K$. lactis yeast species were identified on the microbiota of pomegranate surface. Kwoniella sp. and $H$. uvarum yeast species were dominated half of the yeast biota on fruit surface. The yeast species belong to genera Kloeckera and Rhodotorula, which were predominant genera in other fruits, were not recorded on the surface of pomegranate.

While the HinfI restriction profile of $H$. uvarum strains was similar to previous results, HhaI restriction profile was different (Guillamon et al. 1998; Rodriguez-Vico et al. 2003; Romano et al. 2009; Baffi et al. 2010; Gibson et al. 2011). The HhaI, HaeIII and HinfI profiles of $C$. zeylanoides yeast strains showed similar restriction patterns with other researches (Guillamon et al. 1998; EsteveZarzoso et al. 1999). Similarly, HinfI, HaeIII and HhaI profiles of M. pulcherrima, A. pullulans and K. lactis yeast species revealed the same restriction pattern previously reported (Guillamon et al. 1998; Esteve-Zarzoso et al. 1999; Rodriguez-Vico et al. 2003; Romano et al. 2009; Baffi et al. 2010; Gibson et al. 2011). We also determined that the restriction profiles of both Kwoniella sp. and $M$. pulcherrima species members were different, but, they were determined as same species with respect to in the sequence analysis of ITS1-5.8S-ITS2 gene region. These results that the same yeast species could possess different restriction profiles as reported before.

Table 1. PCR-RFLP profiles of yeast strains

\begin{tabular}{|c|c|c|c|c|c|c|c|}
\hline $\begin{array}{l}\text { PCR Group } \\
\text { no. } \\
\end{array}$ & $\begin{array}{c}\text { Rest. } \\
\text { Profile }\end{array}$ & $\begin{array}{l}\text { Yeast } \\
\text { Strain }\end{array}$ & $\begin{array}{c}\text { HinfI } \\
(\text { bp) }\end{array}$ & $\begin{array}{l}\text { HaeIII } \\
\text { (bp) }\end{array}$ & $\begin{array}{c}\text { MspI } \\
\text { (bp) }\end{array}$ & $\begin{array}{r}\text { AluI } \\
(\text { bp) }\end{array}$ & $\begin{array}{r}\text { HhaI } \\
\text { (bp) }\end{array}$ \\
\hline Group I & 1 & P-25a, P-47, P-49, P-53, P-55a & $195 / 191$ & $287 / 106$ & $217 / 117 / 50$ & - & $217 / 95$ \\
\hline$(\sim 400 \mathrm{bp})$ & 2 & P-48 & $195 / 191$ & $389 / 284 / 106$ & $217 / 117 / 50$ & - & $217 / 95$ \\
\hline \multirow[t]{4}{*}{$\begin{array}{l}\text { Group II } \\
(\sim 600-700 \mathrm{bp})\end{array}$} & 3 & $\begin{array}{l}\text { P-1, P-4, P-5, P-6, P-7, P-9, } \\
\text { P-11, P-12, P-19, P-22, P-26, P- } \\
39, \text { P-41, P-42 }\end{array}$ & 296/185/145 & - & $\begin{array}{l}198 / 152 / 143 / \\
100\end{array}$ & - & $325 / 215$ \\
\hline & 4 & P-3, P-21, P-24, P-27 & 294/177/138 & $465 / 155$ & $284 / 188 / 150$ & $390 / 208$ & 190/185/103/91 \\
\hline & 5 & P-15 & 294/177/138 & - & $284 / 188 / 150$ & - & $331 / 210 / 107$ \\
\hline & 6 & P-30, P-31 & 294/177/138 & - & $\begin{array}{l}200 / 150 / 143 / \\
100\end{array}$ & - & $331 / 210 / 107$ \\
\hline \multirow[t]{2}{*}{$\begin{array}{l}\text { Group III } \\
(\sim 600-700 \mathrm{bp})\end{array}$} & 7 & $\begin{array}{l}\text { P-20, P-25b, P-29, P-32, } \\
\text { P-33, P-34, P-35 }\end{array}$ & $321 / 313$ & $432 / 142 / 82$ & - & - & $304 / 298$ \\
\hline & 8 & $\mathrm{P}-14$ & $320 / 215 / 95$ & - & $197 / 145 / 145 / 99$ & - & $289 / 177 / 140$ \\
\hline \multirow[t]{2}{*}{$\begin{array}{l}\text { Group IV } \\
(\sim 750-800 \mathrm{bp})\end{array}$} & 9 & $\begin{array}{l}\text { P-8, P-23, P-36, P-37, P-38, P-44 } \\
\text { P-46, P-50, P-51, P-52, P-55b }\end{array}$ & $354 / 191 / 166$ & - & - & $585 / 185$ & $339 / 114 / 108 / 99$ \\
\hline & 10 & P-18 & $306 / 189 / 109 / 90$ & $677 / 62$ & - & $428 / 188 / 136$ & $303 / 202 / 109$ \\
\hline
\end{tabular}


The developing molecular identification methods allow researchers to identify more accurate and rapid identification of yeast species than traditional methods. The PCR-RFLP and sequence analysis of ITS1-5.8S-ITS2 gene region has been generally utilized for this purpose. Although, the sequence analysis of ITS1-5.8S-ITS2 gene region is available for determination of yeast microbiota, it could not be useful for some yeast strains. For example, in this study, 18 yeast strains showed low similarity with Kwoniella sp. (80-83\%). It is thought that above $95 \%$ nucleotide identity could be convenient to identify yeast strains, but below 95\% nucleotide identity could not be sufficient. Therefore, additional identification methods should be utilized to determine Kwoniella sp. strains, such as biochemical analysis and morphological features. HinfI, HaeIII, and HhaI (CfoI) endonucleases have been commonly used for identification and differentiation of yeast strains. In this study, we used additional two different restriction enzymes, MspI and AluI, for discrimination of yeast strains such as Kwoniella sp. yeast species.

Table 2. BLAST results of ITS1-5.8S-ITS2 rDNA gene region

\begin{tabular}{|c|c|c|c|c|}
\hline $\begin{array}{c}\text { Yeast } \\
\text { strains }\end{array}$ & $\begin{array}{l}\text { Identified yeast strains } \\
\text { (reference accession no.) }\end{array}$ & $\begin{array}{c}\text { Identity } \\
(\%)\end{array}$ & $\begin{array}{c}\text { GenBank } \\
\text { accession no. }\end{array}$ & References \\
\hline $\mathrm{P}-1$ & K. bestiolae (KY103928.1; CBS: 10118) & 82.58 & KY366236 & Vu et al. 2016 \\
\hline P-3 & A. pullulans (KT898651.1; Strain Code: A85) & 99.61 & MK613238 & Carvalho et al. 2016 \\
\hline P-4 & K. bestiolae (KY103928.1; CBS: 10118) & 82.33 & MK613239 & Vu et al. 2016 \\
\hline P-5 & K. bestiolae (KY103928.1; CBS: 10118) & 82.33 & MK613240 & Vu et al. 2016 \\
\hline P-6 & K. bestiolae (KY103928.1; CBS: 10118) & 82.26 & MK613241 & Vu et al. 2016 \\
\hline P-7 & K. bestiolae (KY103928.1; CBS: 10118) & 82.40 & MK613242 & Vu et al. 2016 \\
\hline P-8 & H. uvarum (KY103563.1; CBS:104) & 99.71 & MK613243 & Vu et al. 2016 \\
\hline P-9 & K. bestiolae (KY103928.1; CBS: 10118) & 82.33 & MK613244 & Vu et al. 2016 \\
\hline P-11 & K. bestiolae (KY103928.1; CBS: 10118) & 82.22 & MK613245 & Vu et al. 2016 \\
\hline P-12 & K. bestiolae (KY103928.1; CBS: 10118) & 82.26 & MK613246 & Vu et al. 2016 \\
\hline P-14 & K. bestiolae (KY103928.1; CBS: 10118) & 82.58 & KY366237 & Vu et al. 2016 \\
\hline $\mathrm{P}-15$ & K. bestiolae (KY103928.1; CBS: 10118) & 82.75 & KY366238 & Vu et al. 2016 \\
\hline P-18 & Kl. lactis (KY103775.1; CBS: 739) & 99.26 & KY366239 & Vu et al. 2016 \\
\hline P-19 & K. bestiolae (KY103928.1; CBS: 10118) & 82.29 & MK613247 & Vu et al. 2016 \\
\hline P-20 & C. zeylanoides (KY102548.1; CBS:641) & 100 & MK613248 & Vu et al. 2016 \\
\hline P-21 & A. pullulans (KT898651.1; Strain Code: A85) & 98.26 & KY366240 & Carvalho et al. 2016 \\
\hline P-22 & K. bestiolae (KY103928.1; CBS: 10118) & 82.33 & MK613249 & Vu et al. 2016 \\
\hline P-23 & H. uvarum (KY103563.1; CBS:104) & 98.70 & KY366241 & Vu et al. 2016 \\
\hline $\mathrm{P}-24$ & A. pullulans (KT898651.1; Strain Code: A85) & 98.88 & KY366242 & Carvalho et al. 2016 \\
\hline P-25a & M. pulcherrima (KY104205.1; CBS:5833) & 96.91 & KY366243 & Vu et al. 2016 \\
\hline $\mathrm{P}-25 \mathrm{~b}$ & C. zeylanoides (KY102548.1; CBS:641) & 100 & MK613250 & Vu et al. 2016 \\
\hline P-26 & K. bestiolae (KY103928.1; CBS: 10118) & 82.29 & MK613251 & Vu et al. 2016 \\
\hline P-27 & A. pullulans (KT898651.1; Strain Code: A85) & 100 & MK613252 & Carvalho et al. 2016 \\
\hline P-29 & C. zeylanoides (KY102548.1; CBS:641) & 100 & MK613253 & Vu et al. 2016 \\
\hline P-30 & K. bestiolae (KY103928.1; CBS: 10118) & 82.31 & KY366244 & Vu et al. 2016 \\
\hline P-31 & K. bestiolae (KY103928.1; CBS: 10118) & 82.33 & MK613254 & Vu et al. 2016 \\
\hline P-32 & C. zeylanoides (KY102548.1; CBS:641) & 99.29 & KY366245 & Vu et al. 2016 \\
\hline P-33 & C. zeylanoides (KY102548.1; CBS:641) & 100 & MK613255 & Vu et al. 2016 \\
\hline P-34 & C. zeylanoides (KY102548.1; CBS:641) & 99.65 & MK613256 & Vu et al. 2016 \\
\hline P-35 & C. zeylanoides (KY102548.1; CBS:641) & 99.65 & MK613257 & Vu et al. 2016 \\
\hline P-36 & H. uvarum (KY103563.1; CBS:104) & 99.42 & KY366246 & Vu et al. 2016 \\
\hline P-37 & H. uvarum (KY103563.1; CBS:104) & 99.56 & MK613258 & Vu et al. 2016 \\
\hline P-38 & H. uvarum (KY103563.1; CBS:104) & 99.71 & MK613259 & Vu et al. 2016 \\
\hline P-39 & K. bestiolae (KY103928.1; CBS: 10118) & 82.29 & MK613260 & Vu et al. 2016 \\
\hline P-41 & K. bestiolae (KY103928.1; CBS: 10118) & 82.15 & MK613261 & Vu et al. 2016 \\
\hline $\mathrm{P}-42$ & K. bestiolae (KY103928.1; CBS: 10118) & 80.48 & MK613262 & Vu et al. 2016 \\
\hline P-44 & H. uvarum (KY103563.1; CBS:104) & 99.56 & MK613263 & Vu et al. 2016 \\
\hline P-46 & H. uvarum (KY103563.1; CBS:104) & 99 & MK613264 & Vu et al. 2016 \\
\hline P-47 & M. ziziphicola (KY104214.1; CBS:10358) & 97.60 & MK613265 & Vu et al. 2016 \\
\hline P-48 & M. pulcherrima (KY104205.1; CBS:5833) & 91.61 & KR011878 & Vu et al. 2016 \\
\hline P-49 & M. ziziphicola (KY104214.1; CBS:10358) & 98 & MK613266 & Vu et al. 2016 \\
\hline $\mathrm{P}-50$ & H. uvarum (KY103552.1) & 98.58 & KY366247 & Vu et al. 2016 \\
\hline P-51 & H. uvarum (KY103563.1; CBS:104) & 99 & MK613267 & Vu et al. 2016 \\
\hline P-52 & H. uvarum (KY103563.1; CBS:104) & 99.42 & MK613268 & Vu et al. 2016 \\
\hline P-53 & M. pulcherrima (KY104205.1; CBS:5833) & 98 & MK613269 & Vu et al. 2016 \\
\hline P-55a & M. ziziphicola (KY104214.1; CBS:10358) & 97.90 & MK613270 & Vu et al. 2016 \\
\hline $\mathrm{P}-55 \mathrm{~b}$ & H. uvarum (KY103563.1; CBS:104) & 99.56 & MK613271 & Vu et al. 2016 \\
\hline
\end{tabular}

Note: Columns indicates the isolated yeast strain code, the BLAST results with the reference strains given in parenthesis, the \% of identity with the BLAST reference strain, the GenBank accession number and references. 


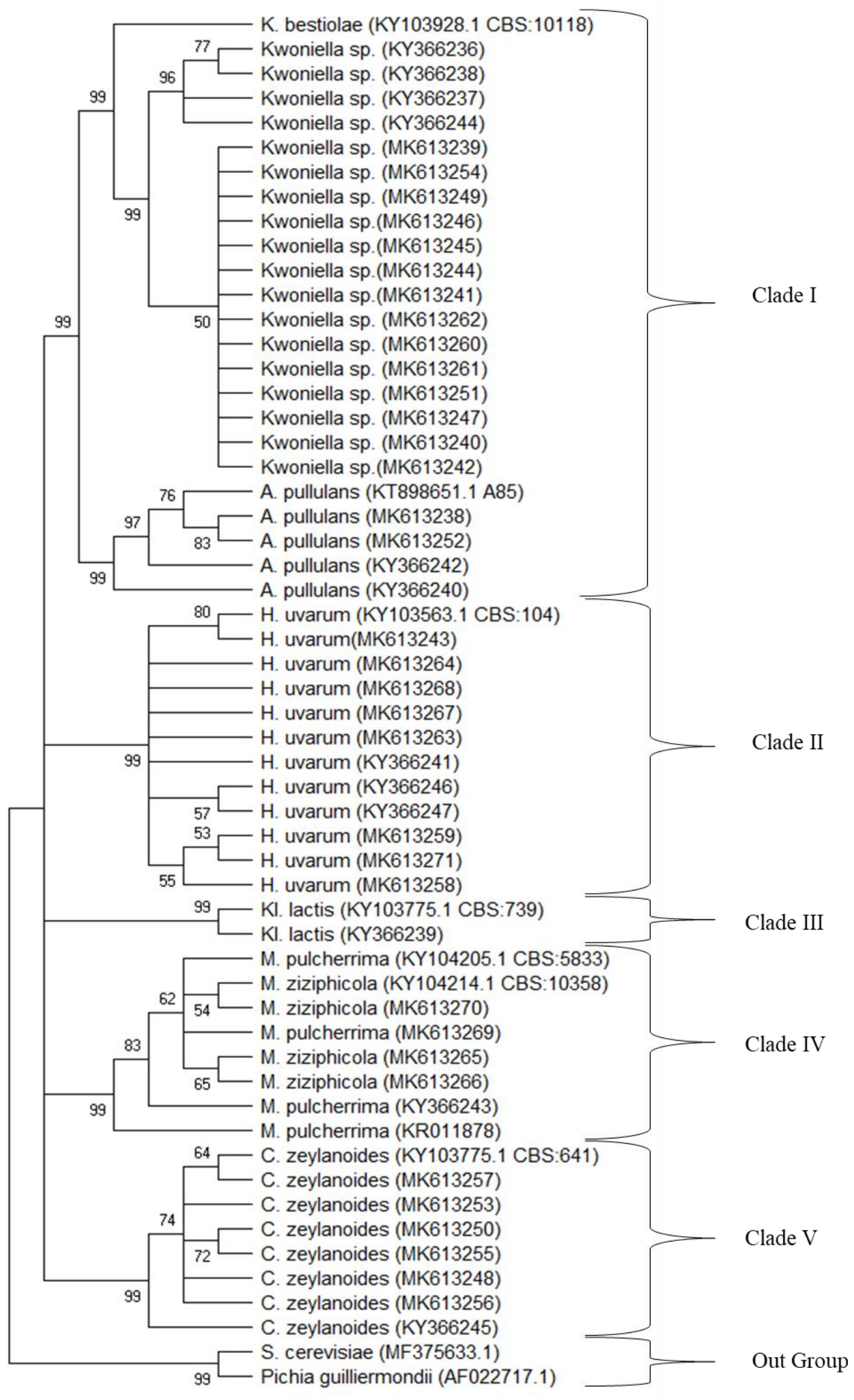

Figure 1. The evolutionary history was inferred using the Maximum Parsimony method. The most parsimonious tree with length $=2305$ is shown. The consistency index is (0.656399), the retention index is (0.904739), and the composite index is $0.593870(0.578885)$ for all sites and parsimony-informative sites (in parentheses). The percentage of replicate trees in which the associated taxa clustered together in the bootstrap test (1000 replicates) are shown next to the branches (Felsenstein 1985). The MP tree was obtained using the SubtreePruning-Regrafting (SPR) algorithm (Nei and Kumar 2000) The analysis involved 54 nucleotide sequences including reference strains' sequences and 2 outgroups in this study, which included 3 M. pulcherrima, 3 M. ziziphicola 18 Kwoniella sp., 4 A. pullulans, 1 K. lactis, $11 \mathrm{H}$. uvarum, and 7 C. zeylanoides yeast strains. S. cerevisiae and P. guilliermondii strains were selected as outgroup. 
Table 3. Extracellular enzyme activity of yeast strains that isolated from pomegranate fruits

\begin{tabular}{|c|c|c|c|c|c|c|c|c|c|c|c|c|c|}
\hline Yeast species & $\mathbf{C}$ & 1 & 2 & 3 & 4 & 5 & 6 & 7 & 8 & 9 & 10 & 11 & 12 \\
\hline $\begin{array}{l}\text { Kwoniella sp. } \\
(\mathrm{P}-1, \text { P-5, P-6, P-7, P-9, P-11, P-19, P-26, P-31, P-41, P-42) }\end{array}$ & 0 & 1 & 3 & 2 & 0 & 4 & 0 & 0 & 1 & 1 & 5 & 0 & 0 \\
\hline $\begin{array}{l}\text { Kwoniella sp. } \\
\text { (P-4, P-12, P-14, P-15, P-22, P-30, P-39) }\end{array}$ & 0 & 0 & 2 & 1 & 0 & 1 & 0 & 0 & 2 & 1 & 0 & 0 & 0 \\
\hline $\begin{array}{l}\text { H. uvarum } \\
\text { (P-23, P-37, P-38, P-55b) }\end{array}$ & 0 & 5 & 0 & 1 & 0 & 4 & 0 & 0 & 0 & 0 & 0 & 0 & 0 \\
\hline $\begin{array}{l}\text { H. uvarum } \\
\text { (P-8, P-36, P-44, P-46, P-50, P-51, P-52,) }\end{array}$ & 0 & 1 & 2 & 1 & 0 & 4 & 1 & 0 & 1 & 1 & 0 & 0 & 5 \\
\hline $\begin{array}{l}\text { C. zeylanoides } \\
\text { (P-20, } \mathrm{P}-25 \mathrm{~b})\end{array}$ & 0 & 0 & 2 & 2 & 0 & 2 & 0 & 0 & 2 & 0 & 0 & 0 & 0 \\
\hline $\begin{array}{l}\text { C. zeylanoides } \\
(\mathrm{P}-29, \mathrm{P}-32, \mathrm{P}-33, \mathrm{P}-34, \mathrm{P}-35)\end{array}$ & 0 & 0 & 2 & 2 & 0 & 2 & 1 & 0 & 2 & 2 & 0 & 0 & 0 \\
\hline $\begin{array}{l}\text { M. pulcherrima } \\
\text { (P-25a, P-47, P-49, P-53, P-55a) }\end{array}$ & 0 & 3 & 3 & 2 & 0 & 4 & 4 & 2 & 3 & 2 & 0 & 3 & 2 \\
\hline $\begin{array}{l}\text { A. pullulans } \\
\text { (P-3, P-21, P-24, P-27) }\end{array}$ & 0 & 0 & 2 & 2 & 0 & 2 & 0 & 0 & 1 & 0 & 0 & 0 & 0 \\
\hline K. lactis $(\mathrm{P}-18)$ & 0 & 5 & 2 & 2 & 1 & 5 & 4 & 1 & 3 & 2 & 1 & 0 & 1 \\
\hline
\end{tabular}

Note: C. Control; 1. Alkaline phosphatase; 2. Esterase (C4); 3. Esterase lipase (C8); 4. Lipase (C14); 5. Leucine arylamidase; 6. Valine arylamidase; 7. Cystine arylamidase; 8. Acid phosphatase; 9. Naphthol-AS-BI-phosphohydrolase; 10. $\beta$-Galactosidase; $11 . \alpha-$ Glucosidase;12. $\beta$-Glucosidase. Due to trypsin, $\alpha$-chymotrypsin, $\alpha$-galactosidase, $\beta$-glucuronidase, $N$-acetyl- $\beta$-glucosaminidase, $\alpha$ mannosidase and $\alpha$-fucosidase enzymes have not shown activity, these enzymes are not shown in this table

$\beta$-galactosidase and $\beta$-glucosidase enzymes hydrolyze glycosidic bonds in oligosaccharides, polysaccharides and heteroglycosides (Karasova et al. 2002). These enzymes have been found various organisms, like bacteria, yeast, fungi. $\beta$-galactosidases are responsible from the breakdown of lactose into glucose and galactose (Shaima et al. 2017). The deficiency of $\beta$-galactosidase enzyme can cause lactose intolerance that is threatened by using $\beta$ galactosidase supplemented foods (Vasiljevic and Jelen 2001). The enzyme of $\beta$-glucosidase (EC 3.2.1.21) hydrolyzed $\beta-1-4$ glycosidic bonds in cellulose molecules. $\beta$-glucosidase enzymes have generally used for various applications like biofuel production, splits of bitter components for juice extraction and contributes to aroma production of wine ( $\mathrm{Li}$ et al. 2013; Gueguen et al. 1998; Harhangi et al. 2002). The $\beta$-glucosidase enzyme has enormous potential for food processing and utilized to increase the flavor of tea and fruit juice (Keerti et al. 2014). Arylamidases (aminopeptidases, EC 3.4.11.2) are the proteolytic enzymes and hydrolyze $\mathrm{N}$-terminal amino acids (Dodor and Tabatabai 2007). Cystine arylamidase, leucine arylamidase, valine arylamidase, acid phosphatase, naphthol-AS-BI-phosphohydrolase, $\alpha$-and $\beta$-glucosidase enzymes have a significant role in enhancing the aroma and flavor of wine (Delfini and Formica 2001; Nikolaou et al. 2007; Nikolaou et al. 2006; Fleet et al. 1997). As shown that extracellular enzymes are important for various fields such as wine industry and medical applications. For this reason, identified yeast strains having high enzyme activities could be used for different industrial applications.

Kwoniella sp., H. uvarum, M. pulcherrima and $\mathrm{Kl}$. lactis yeast strains showed high leucine arylamidase activity. Also valine arylamidase activity was determined in $M$. pulcherrima and $K l$. lactis yeast species, acid phosphatase activity in $H$. uvarum and $K l$. lactis yeast species. Kwoniella sp. and $H$. uvarum yeast species displayed high $\beta$-galactosidase and $\beta$-glucosidase activities, respectively. The obtained results in this study showed that the same yeast species could be different extracellular enzyme profiles. Therefore, variety of extracellular enzyme profiles of yeast strains could be used for discrimination of same yeast strains. Eleven yeast strains belonging to Cryptococcus genus were investigated for determining the extracellular enzyme profile and the results showed that the members of $\mathrm{Cr}$. laurentii and $\mathrm{Cr}$. neoformans yeast species have different enzyme profiles (Garcia-Martos et al. 2001).

M. pulcherrima yeast species are used as biocontrol agent to the agricultural areas. It has also shown protective features for post-harvest pathogens, especially, causing by Botrytis cinerea (De Curtis et al. 1996; Piano et al. 1997; Spadaro et al. 2002). H. uvarum which is also a potential biocontrol agent, had an antagonistic effect for inhibiting spore formation of B. cinerea (Liu 2010a, b). A. pullulans yeast species have been used as indicator of environmental pollution (Deshpande et al. 1992). They have also synthesized an extracellular polysaccharide, pullulan, used in food and pharmaceutical industry (Bernier 1958; Sena et al. 2006; Cheng et al. 2011). C. zeylanoides yeast strains could display a remarkable ability of removing color of sulphonic and non-sulphonic dyes, at acidic $\mathrm{pH}$ and synthetic medium (Ramalho et al. 1999). Therefore, $M$. pulcherrima and $A$. pullulans yeast species are industrially important yeasts due to having high alpha-and beta- $\beta$ glucosidase activities, respectively. In addition, $\mathrm{Cr}$. bestiolae yeast species is also good candidate for industrially production of $\beta$-galactosidase enzyme. Extracellular enzymes are used for different areas such as wine industry, medical applications, textile industry, 
baking industry. For this reason, the determining of yeast strains which have high enzyme activity is highly significant for producer.

\section{ACKNOWLEDGEMENTS}

This work was supported by Çanakkale Onsekiz Mart University, Turkey trought The Scientific Research Coordination Unit, Project number: FYL-2014-110. The authors declare that they have no conflict of interests.

\section{REFERENCES}

Altschul SF, Gish W, Miller W, Myers EW, Lipman DJ. 1990. Basic local alignment search tool. J Mol Biol 215: 403-410.

Aslan A, Can Mİ, Boydak D. 2014. Anti-Oxidant effects of pomegranate juice on Saccharomyces cerevisiae cell growth. Afr J Tradit Compl Altern Med 11: 14-18.

Baffi MA, Bezerra CS, Arévalo-Villena M, Briones-Pérez AI, Gomes E, Da Silva R. 2010. Isolation and molecular identification of wine yeasts from a Brazilian vineyard. Ann Microbiol 61: 75-78.

Bakoyianis V, Kanellaki M, Kalliafas A, Koutinas AA. 1992. Low temperature wine making by immobilized cells on mineral kissiris. J Agric Food Chem 40: 1293-1296.

Baleiras Couto MM, Reizinho RG, Duarte FL. 2005. Partial 26S rDNA restriction analysis as a tool to characterize non-Saccharomyces yeasts present during red wine fermentation. Intl $\mathrm{J}$ Food Microbiol 102: 49-56.

Barnett JA, Payne RW, Yarrow D. 2000. Yeasts: characteristics and identification. Cambridge University Press, Cambridge.

Bernier B, (1958). The production of polysaccharides by fungi active in the decomposition of wood and forest litter. Can J Microbiol 4: 195204.

Braduardi, P., Porro, D., (2012). Yeast in biotechnology. In: Feldmann H (ed.). Yeast: Molecular and Cell Biology, Wiley-Blackwell, Germany.

Cadez N, Raspor P, de Cock AW, Boekhout T, Smith MT. 2002. Molecular identification and genetic diversity within species of the genera Hanseniaspora and Kloeckera. FEMS Yeast Res. 1: 279-289.

Cheng CK, Demirci A, Catchmark MJ. 2011. Pullulan: Biosynthesis, production and applications. Appl Microbiol Biotechnol 92: 29-44.

Dağcı KE, Dığrak M. 2005. Bazı meyve ekstraktlarının antibakteriyal ve antifungal aktiviteleri. KSÜ Fen ve Mühendislik Dergisi 8 (2): 1-7.

De Curtis E, Torriani, S, Rossi E, De Cicco V. 1996. Selection and use of Metschnikowia Pulcherrima as a biological control agent for postharvest rots of peaches and table grapes. Annali de Microbiologia ed Enzymologia 46: 45-55.

Delfini C, Formica JV. 2001. Wine Microbiology Science and Technology. Marcel Dekker Inc., Italy.

Deshpande MS, Rale VB, Lynch JM. 1992. Aureobasidium pullulans in applied microbiology: A status report. Enzyme Microb Technol 14 514-527.

Diaz MR, Fell JW. 2000. Molecular analysis of the IGS \& ITS regions of rDNA of the psychrophilic yeasts in the genus Mrakia. Antonie van Leuwenhoek 77: 7-12.

Dodor DE, Tabatabai MA. 2007. Arylamidase activity as an index of nitrogen mineralization in soils. Commun Soil Sci Plant Anal 8: 2197-2207.

Esteve-Zarzoso B, Belloch C, Uruburu F, Querol A. 1999. Identification of Yeasts by RFLP analysis of the 5.8S rRNA gene and the two ribosomal internal transcribed spacers. Intl J Sys Bacteriol 49: 329337.

Felsenstein J. 1985. Confidence limits on phylogenies: An approach using the bootstrap. Evolution. 39: 783-791.

Fleet GH, Charoenchai C, Henschke PA, Todd BEN. 1997. Screening of non-Saccharomyces wine yeasts for the presence of extracellular hydrolytic enzymes. Aus J Grape Wine Res 3: 2-8.

Garcia-Martos P, Marin P, Hernandez-Molina JM, Garcia-Agudo L, Aoufi S, Mira J. 2001. Extracellular enzymatic activity in 11 Cryptococcus species. Mycopathologia 150: 1-4.
Gibson BR, Pham T, Wimalasena T, Box WG, Koivuranta K, Storgards E, Smart KA. 2011. Evaluation of ITS PCR and RFLP for differentiation and identification of brewing yeast and brewery 'wild' yeast contaminants. J Inst Brew 117: 556-568.

Gonzalez SS, Barrio E, Querol A. 2007. Molecular identification and characterization of wine yeasts isolated from Tenerife (Canary Island, Spain). J Appl Microbiol 102 (4): 1018-1025. DOI: 10.1111/j.13652672.2006.03150.x

Gueguen Y, Chemardin P, Janbon G, Arnaud A, Galzy P. 1998. Investigation of the $\beta$-glucosidases potentialities of yeast strains and application to bound aromatic terpenols liberation. Stud Org Chem 53: 149-157.

Guillamon JM, Sabate J, Barrio E, Cano J, Querol A. 1998. Rapid identification of wine yeast species based on RFLP analysis of the ribosomal internal transcribed spacer (ITS) region. Arch Microbiol 169: 387-392.

Harhangi HR, Steenbakkers PJM, Akhmanova A, Jetten MSM, van der Drift C, Op den Camp HJM. 2002. A highly expressed family $1 \beta$ glucosidase with transglycosylation capacity from the anaerobic fungus Piromyces sp. E2. Biochimica et Biophysica Acta. 1574: 293303.

Hierro N, Gonzalez A, Mas A, Guillamon JM. 2004. New PCR-based methods for yeast identification. J Appl Microbiol. 97: 792-801. DOI: 10.1111/j.1365-2672.2004.02369.x.

Johnson EA. 2013a. Biotechnology of non-Saccharomyces yeasts - the Ascomycetes Appl Microbiol Biotechnol 97 (2): 503-517. DOI: 10.1007/s00253-012-4497-y

Johnson EA. 2013b. Biotechnology of non-Saccharomyces yeasts-the Basidiomycetes Appl Microbiol Biotechnol 97 (17): 7563-7577. DOI: 10.1007/s00253-013-5046-Z

Karasova P, Spiwok V, Mala S, Kralova B, Russell NJ. 2002: Betagalactosidase activity in psychrotrophic microorganisms and their potential use in food industry. Czech J Food Sci 20: 43-47.

Keerti GA, Kumar V, Dubey A, Verma AK. 2014. Kinetic characterization and effect of immobilized thermostable $\beta$ glucosidase in alginate gel Beads on sugarcane juice. ISRN Biochem 2014: 178498. DOI: 10.1155/2014/178498.

Kılıçgün H, Arda N, Uçar EÖ. 2015. Identification of longevity, fertility and growth-promoting properties of pomegranate in Caenorhabditis elegans. Pharmacogn Mag 11: 356-359.

Kreger-van Rij NJW. 1984. The yeast, a taxonomic study. Elsevier Science B.V., Amsterdam, Netherlands.

Kumar S, Stecher G, Li M, Knyaz C, Tamura K. 2018. MEGA X: Molecular Evolutionary Genetics Analysis across computing platforms. Mol Biol Evol 35: 1547-1549.

Kurtzman CP, Fell JW. 1998. The Yeasts: A Taxonomic Study, 4th ed. Elsevier Science Publishers, Amsterdam.

Kurtzman CP, Robnett CJ. 1998) Identification and phylogeny of ascomycetous yeasts from analysis of nuclear large subunit (26S) ribosomal DNA partial sequences. Antonie van Leeuwenhoek 73: 331-371.

Lee BH. 1996. Fundamentals of Food Biotechnology, VCH Publishers, USA.

Li D, Li X, Dang W, Tran PL, Park S, Oh B, Hong W, Lee J, Park K. 2013. Characterization and application of an acidophilic and thermostable $\beta$-glucosidase from Thermofilum pendens. J Biosci Bioeng 115 (5): 490-496.

Liu HM, Guo JH, Cheng YJ, Luo L, Liu P, Wang BQ, Deng BX, Long CA. 2010a. Improvement of Hanseniaspora uvarum biocontrol activity against gray mold by the addition of ammonium molybdate and the possible mechanisms involved. Crop Protect 29: 277-282.

Liu HM, Guo JH, Cheng YJ, Luo L, Liu P, Wang BQ, Deng BX, Long CA. 2010b Control of gray mold of grape by Hanseniaspora uvarum and its effects on postharvest quality parameters. Ann Microbiol 60: 31-35.

Lopez V, Querol A, Ramon D, Fernandez-Espinar MT. 2001. A simplified procedure to analyze mitochondrial DNA from industrial yeasts. Intl J Food Microbiol 68: 75-81.

Naumova ES, Korshunova IV, Jespersen L, Naumov GI. 2003. Molecular genetic identification of Saccharomyces sensu stricto strains for African sorghum beer. FEMS Yeast Res 3: 177-184.

Nei M, Kumar S. 2000. Molecular Evolution and Phylogenetics. Oxford University Press, New York.

Nikolaou E, Andrighetto C, Lombardi A, Nikolaos T. 2007. Heterogeneity in genetic and phenotypic characteristics of Saccharomyces cerevisiae 
strains isolated from red and white wine fermentations. Food Control 18: $1458-1465$

Nikolaou E, Soufleros EH, Boulompasi E, Tzanetakis N. 2006. Selection of indigenous Saccharomyces cerevisiae strains according to their oneological characteristics and vinification results. Food Microbiol 23 (3): 205-211.

Paiva de Carvalho H, Mesquita N, Trovao J, Peixoto da Silva J, Rosa B, Martins R, Bandeira AML, Portugal A. 2016. Diversity of fungal species in ancient parchments collections of the Archive of the University of Coimbra. Intl Biodeter Biodegrad 108: 57-66.

Piano S, Neyrotti V, Migheli Q, Gullino ML. 1997. Biocontrol capability of Metschnikowia pulcherrima against Botrytis postharvest rot of apple. Postharvest Biol Technol 11: 131-140.

Ramalho MT, Martin MAM, Cardoso MH, Queiroz MJ, Campos AMO 1999. Biodegradation of azo dyes by the yeast Candida zeylanoides in batch aerated cultures. Chemosphere 38: 2455-2460.

Rodriguez-Vico F, Clemente-Jimenez JM, Mingorance-Cazorla L, Martinez-Rodriguez S, Las Heras-Vazquez FJ. 2003. Molecular characterization and oenological properties of wine yeasts isolated during spontaneous fermentation of six varieties of grape must. Food Microbiol 21: 149-155.

Romano P, Capece A, Siesto G, Romaniello R. 2009. Restriction analysis of rDNA regions to differentiate non-Saccharomyces wine species in mixed cultures. J Eng Technol Res 1 (4): 68-71.

Sabate J, Cano J, Esteve-Zarzoso B, Guillamon JM. 2002. Isolation and identification of yeast associated with Vineyard and winery by RFLP analysis of ribosomal genes and mitochondrial DNA. Microbiol Res 157: $267-274$.

Santos EV Martinez AO, Munizaga GT, Reyes JE, Won MP. 2012. Effect of high hydrostatic pressure (HHP) processing on physicochemical properties, bioactive compounds and shelf-life of pomegranate juice. Innov Food Sci Emerg Technol 13: 13-22.

Sena RF, Costelli MC, Gibson LH, Coughlin RW. 2006. Enhanced production of pullulan by two strains of A. pullulans with different concentrations of soybean oil in sucrose solution in batch fermentations. Braz J Chem Eng 23 (4): 507-515.

Sevda SB, Rodrigues L, 2011. The making of pomegranate wine using yeast immobilized on sodium alginate. Afr J Food Sci 5: 299-304.
Shaima S, Akram A, Halim SA, Tassaduq R, 2017. Sources of $\beta$ galactosidase and its applications in food industry. 3 Biotechnology 7 (1): 79. DOI 10.1007/s13205-017-0645-5.

Sherman F, Fink GR, Hicks JB. 1986. Methods in yeast genetics. Cold Spring Harbor, NY: Cold Spring Harbor Laboratory.

Spadaro D, Vola R, Piano S, Gullino ML. 2002. Mechanisms of action and efficacy of four isolates of the yeast Metschnikowia pulcherrima active against postharvest pathogens on apples. Postharvest Biol Technol 24: 123-134.

Török T, Rockhold D, King AD. 1993. Use of electrophoretic karyotyping and DNA-DNA hybridization in yeast identification. Intl $\mathrm{J}$ Food Microbiol 19: 63-80.

Vasiljevic T, Jelen P. 2001. Production of $\beta$-galactosidase for lactose hydrolysis in milk and products using thermophilic lactic acid bacteria. Innov Food Sci Emerg Technol 2: 75-85.

Vaughan Martini A, Martini A. 1987. Taxonomic revision of the yeast genus Kluyveromyces by nuclear deoxyribonucleic acid reassociation. Intl J Sys Bacteriol 37 (4): 380-385.

Versavaud A, Hallet JN. 1995. Pulsed-Field gel electrophoresis combined with rare-cutting endonucleases for strain identification of Candida famata, Kloeckera apiculata and Schizosaccharomyces pombe with chromosome number and size estimation of the two former. Sys Appl Microbiol 18: 303-309.

Vu D, Groenewald M, Szöke S, Cardinali G, Eberhardt U, Stielow B, de Vries M, Verkleij GJM, Crous PW, Boekhout T, Robert V. 2016. DNA barcoding analysis of more than 9000 yeast isolates contributes to quantitative thresholds for yeast species and genera delimitation. Stud Mycol 85: 91-105.

Wang X, Li S, Yang X, Yang S, Zhu M. 2012. Technology prospecting on enzymes: application, Market Eng 2 (3): 1-11.

White TJ, Bruns T, Lee S, Taylor J. 1990. Amplification and direct sequencing of fungal ribosomal RNA genes for phylogenetics. In: Innis MA, Gelfand DH, Sninsky JJ, White TJ (eds.). PCR Protocols: A Guide to Methods and Applications Academic Press, San Diego, CA.

Yasoubi P, Barzegar M, Sahari MA, Azizi MH. 2007. Total phenolic contents and antioxidant activity of pomegranate (Punica granatum L.) peel extracts. J Agric Sci Technol 9: 35-42. 